\title{
Carbon and nitrogen stable isotope analyses of mammal bone fossils from the Zhongba site in the Three Gorges Reservoir region of the Yangtze River, China
}

\author{
TIAN XiaoSi ${ }^{1,2}$, ZHU Cheng ${ }^{3 *}$, SUN ZhiBin ${ }^{4}$, SHUI Tao ${ }^{1}$, HUANG YunPing ${ }^{5}$, \\ FLAD Rowan Kimon ${ }^{6} \&$ LI YuMei ${ }^{7}$ \\ ${ }^{1}$ The Department of History of Nanjing University, Nanjing 210093, China; \\ ${ }^{2}$ Department of Tourism of Chizhou College, Chizhou 247100, China; \\ ${ }^{3}$ School of Geographic and Oceanographic Sciences of Nanjing University, Nanjing 210093, China: \\ ${ }^{4}$ Institute of Cultural Relics and Archaeology, Chengdu 610041, China; \\ ${ }^{5}$ Faculty of Archaeology and Museology, Peking University, Beijing 100871, China; \\ ${ }^{6}$ Department of Anthropology, Peabody Museum, Harvard University, Cambridge, MA 02138, USA; \\ ${ }^{7}$ Graduate University of Chinese Academy of Sciences, Beijing 100049, China
}

Received April 27, 2010; accepted September 25, 2010

Based on AMS ${ }^{14} \mathrm{C}$ dating data, carbon and nitrogen isotope analyses were conducted on mammal bone collagen of deer, cattle and pigs from the Zhongba site in the Three Gorges Reservoir region of the Yangtze River. These analyses were conducted to reconstruct palaeodiets of mammals, palaeoecology, palaeoenviroment and previous human activities in the study area. Results show that the collagen loss of bone did not change the in vivo isotopic composition of carbon and nitrogen stable isotopes, and most of the bone fossils were well preserved. The bone collagen of samples from deer had a mean $\delta^{13} \mathrm{C}$ of $-23.1 \%$ and a mean $\delta^{15} \mathrm{~N}$ of $4.7 \%$, suggesting that deer subsisted in a closed habitat and fed on branches and leaves. The bone collagen of cattle had a mean $\delta^{13} \mathrm{C}$ of $-19.6 \%$ and a mean $\delta^{15} \mathrm{~N}$ of $5.2 \%$, which indicates that cattle subsisted in an open habitat and fed on grasses and stems. The $\delta^{13} \mathrm{C}$ values show that both deer and cattle fed on $\mathrm{C}_{3}$ plants and lived in the same ecosystem, but the $t$-test results show that deer $\delta^{13} \mathrm{C}$ and $\delta^{15} \mathrm{~N}$ values were both more negative than those of cattle, indicating that they inhabited different niches. The $\delta^{13} \mathrm{C}$ and $\delta^{15} \mathrm{~N}$ values of cattle partially overlapped those of deer, suggesting some competition in diets between them. The $t$-tests show that the $\delta^{13} \mathrm{C}$ and $\delta^{15} \mathrm{~N}$ values of pigs were more positive than those of cattle and deer, which signifies that pigs occupied a higher trophic level compared to cattle and deer. The wide range of pig $\delta^{13} \mathrm{C}$ values demonstrates that pig trading had been taking place from early Neolithic Age to late Bronze Age. There were no significant differences in deer $\delta^{13} \mathrm{C}$ and $\delta^{15} \mathrm{~N}$ values among different archaeological periods, making it clear that climatic, ecological and environmental conditions were kept relatively stable from 2200 to 4200 a BP. This stability may have been responsible for the extensive and complete cultural layers at the Zhongba site. The minimum number of samples required to estimate the mean $\delta^{13} \mathrm{C}$ values of deer, pigs and cattle are 8,73 and 16 , respectively, and for mean $\delta^{15} \mathrm{~N}$ values of deer, pigs and cattle, the minimum numbers are 4, 5 and 6 , respectively.

Zhongba site, bone collagen, $\delta^{13} \mathrm{C}, \delta^{15} \mathrm{~N}$, palaeodiet, palaeoclimate, palaeoecology

Citation: Tian X S, Zhu C, Sun Z B, et al. Carbon and nitrogen stable isotope analyses of mammal bone fossils from the Zhongba site in the Three Gorges Reservoir region of the Yangtze River, China. Chinese Sci Bull, 2011, 56: 169-178, doi: 10.1007/s11434-010-4213-1

The ratios of $\mathrm{C}$ and $\mathrm{N}$ stable isotopes from animal tissues can be well preserved in collagen of bone fossils. The bone

*Corresponding author (email: zhuchengnj@yahoo.com.cn) collagen $\delta^{13} \mathrm{C}$ and $\delta^{15} \mathrm{~N}$ values reflect the mean $\mathrm{C}$ and $\mathrm{N}$ stable isotopic compositions in bone collagen during the mean lifetime, which provides information about the dietary preference of an individual. Climate may affect the $\delta^{13} \mathrm{C}$ and 
$\delta^{15} \mathrm{~N}$ values of terrestrial mammals through its effect on plant $\delta^{13} \mathrm{C}$ and $\delta^{15} \mathrm{~N}$ values [1-3]. Thus, analyses of $\mathrm{C}$ and $\mathrm{N}$ stable isotopic compositions in bone are used widely in archaeology [4,5]. Since the 1960s, many studies on palaeodiet, palaeoenviroment and human activities have been conducted using $\mathrm{C}$ and $\mathrm{N}$ stable isotopic compositions in bone collagen. For example, a set of mammal herbivore bones were studied for $\mathrm{C}$ and $\mathrm{N}$ stable isotopic compositions in bone collagen to reconstruct Pleistocene environment and ecology in Italy [6]. Moreover, climatic evolution of the last 5000 years in Europe was revealed by analysis of $\mathrm{C}$ and $\mathrm{N}$ stable isotopic compositions of cattle, deer and horse bone collagen [7]. Furthermore, the status, region and gender differences in diets were inferred by $\mathrm{C}$ and $\mathrm{N}$ isotopic analyses of human bones in the Mississippi River valley [8]. In China, relevant studies have been carried out since the 1980s. Many of these studies used analyses of bone elements and isotopes to determine the diet of ancient people $[9,10]$. Recently, much progress has been made to reconstruct rice cultivation strategies and food source acquisition techniques for prehistoric societies [11,12].

The Zhongba site is located about $6 \mathrm{~km}$ distant from the confluence of the Ganjin and Yangtze rivers. The site is situated on an alluvial fan on the bank of the Ganjin River, and has an area of $8000 \mathrm{~m}^{2}$. The central geographic coordinates of the site are $30^{\circ} 20^{\prime} 43^{\prime \prime} \mathrm{N}$ and $108^{\circ} 1^{\prime} 38^{\prime \prime} \mathrm{E}$. The Zhongba site has yielded the thickest and most complete layers found in the Three Gorges region. This was mostly due to the rescue excavation carried out and the profile of the T0102 unit of the site, which has many cultural layers covering the past 5000 years. These include: the Neolithic Age, the Xia Dynasty, the Shang Dynasty, the Western Zhou Dynasty, the Spring and Autumn Period and the Warring States, the Han Dynasty, the Six Dynasty Period, the Tang Dynasty, the Song Dynasty, the Ming Dynasty and the Qing Dynasty [13]. Based on $\mathrm{AMS}^{14} \mathrm{C}$ dating data, carbon and nitrogen isotope analyses on mammal bone collagen of deer, cattle and pigs from the Zhongba site in the Three Gorges reservoir of the Yangtze River were performed to reconstruct mammal palaeodiets, palaeoecology, palaeoenviroment and human activities. The minimum number of specimens that should be analyzed to estimate mean $\delta^{13} \mathrm{C}$ and $\delta^{15} \mathrm{~N}$ values of deer, pigs and cattle are provided herein, based on the corresponding standard deviations of bone collagen $\delta^{13} \mathrm{C}$ and $\delta^{15} \mathrm{~N}$ values.

\section{Rationale}

\subsection{Carbon isotopes}

Based on photosynthetic pathways for fixing atmospheric $\mathrm{CO}_{2}$ [14], the plants are divided into three categories. $\mathrm{C}_{3}$ pathway and $\mathrm{C}_{4}$ pathways are the two principal pathways that fractionate carbon isotopes to different degrees, result- ing in plants with non-overlapping isotope compositions. $\mathrm{C}_{3}$ plants typically are temperate plants, including trees, herbs, shrubs, and cool-climate grasses, which have a wide range in $\delta^{13} \mathrm{C}$ values. Water-stressed ecosystems in arid environments are enriched in ${ }^{13} \mathrm{C}$, and the pants have more positive values (as high as $-21 \%$ o) than the mean $\mathrm{C}_{3} \delta^{13} \mathrm{C}$ value of $-27 \%$. Conversely, closed forest plants have lower $\delta^{13} \mathrm{C}$ values (as low as $-35 \%$ ) relative to the trees in open habitats because of the canopy effect [15]. In contrast, $\mathrm{C}_{4}$ plants, including sedges and temperate and tropic grasses, grow in open environments and their $\delta^{13} \mathrm{C}$ values are independent of the water stress, having mean $\delta^{13} \mathrm{C}$ values of $-12.5 \%$, with a restricted range of from $-10 \%$ o to $-14 \%$ o [16]. The isotopes of plants are fractionated in the tissues of consumers, resulting in positive shift in $\delta^{13} \mathrm{C}$ values. This indicates the difference in $\delta^{13} \mathrm{C}$ values between the animals and plants consumed. The fractionation factors are different depending on which tissues are analyzed. Compared with the $\delta^{13} \mathrm{C}$ values of plants consumed, enrichments for animal muscle and bone collagen are about $1 \%$ and 5\%, respectively. For hydroxyapatite carbonate in bone, the enrichment can be up to $12 \%$. Thus, by analyzing the $\delta^{13} \mathrm{C}$ values of herbivore bone collagen, we can infer the plants upon which the animals fed, and hence the contemporary climate and environment in which they lived [17].

\subsection{Nitrogen isotopes}

The $\delta^{15} \mathrm{~N}$ values in soil range considerably, from about $-7 \%$ o to $18 \%$. The nitrogen fixation progress is influenced by the climate, with high temperatures and arid environments affecting the progress negatively. The depth of plant roots and seasonal changes also impact on $\delta^{15} \mathrm{~N}$ values in the soil [18]. Hence $\mathrm{N}$ isotopic signatures may indicate the trophic level that the animals occupied and the protein sources of consumers. The animals enrich the $\delta^{15} \mathrm{~N}$ values of plants by about $3 \%$ to $5 \%$, although some studies have shown that consumers may be $6 \%$ more positive than the diets they consume. There is still no accepted theory that can model the $\delta^{15} \mathrm{~N}$ values in plants. The plants that can directly fix nitrogen usually are leguminous plants, such as beans, and yielding about 0 in their $\delta^{15} \mathrm{~N}$ values. The herbivore animal $\delta^{15} \mathrm{~N}$ will be elevated from $3 \%$ to $4 \%$ over the plants, and the effect is such that the same enrichment over dietary protein occurs at every trophic level of the food chain [19]. Marine food chains have much longer trophic levels relative to terrestrial food chains. This could be responsible for the elevated marine fish $\delta^{15} \mathrm{~N}$ that is more positive than $10 \%$, and the same applies to the freshwater food chains, which is demonstrated by freshwater fishes also having enriched $\delta^{15} \mathrm{~N}$ [20]. Animals in arid environments have more positive $\delta^{15} \mathrm{~N}$ values because of excretion of urine and sweat of animals, which enriches $\delta^{15} \mathrm{~N}$. 


\section{Materials and methods}

\subsection{Profile characteristics of the site}

The bone samples collected were from levels 17-68. Level 17, together with the upper levels, dates to the Qin and Han dynasties. Levels 17-33, 34-43, 44-53, 49B-52B, 54-68 and 69 correspond to the Warring States, the Spring and Autumn Period, the Western Zhou Dynasty, the Shang Dynasty and the Xia Dynasty, the early of Neolithic Age and raw soil disturbed by ashpits of the Neolithic Age, respectively. Excavations conducted at the archaeological site resulted in at least 33 species of mammals, 18 species of fishes, and numerous unidentified birds, amphibians and reptiles. The most common mammals belonged to Artiodactyla, Carnivora, Lagomorpha, Perissodactyla, Primate, Rodentia, Artiodactyla including Bovidae (Bos sp., Bubalus sp.), Cervidae (Cervus albirostris, Cervus elaphus, Cervus sp., Elaphurus davidianus, Hydropodes inerm, Muntiacus reevesi and Muntiacus sp.), Suidae (Sus scrofa) and other indeterminate taxa. Primates included Homo sapiens, Macaca mulatta, Macaca sp., Rhinopithecus sp., Presbytis sp. and other indeterminate taxa. Here bone samples of cattle, deer and pigs, ranging from early Neolithic Age to late Bronze Age, were analyzed to reconstruct paleoenvironments and the paleodiets of animals.

\section{2 $\mathrm{AMS}^{14} \mathrm{C}$ dating}

The layer ages of the Zhongba site were determined by $\mathrm{AMS}^{14} \mathrm{C}$ dating of 27 animal bones and 5 charcoals. The analyses were conducted at the Institute of Heavy Ion Physics, Peking University. The corresponding ages are shown in Figure 1 and Table 1 [21].

\subsection{Carbon and nitrogen isotope analyses}

Bone samples were pretreated according to the method of Koch et al. [22]. Surface contamination of the bones was removed with a drill and a scalpel. Then, a piece of bone an was finely ground in an agate mortar to a size of less than $75 \mu \mathrm{m}$. Bone powder was collected and accurately weighed in an electronic balance. Next, the powder was decalcified in $0.1 \mathrm{~mol} / \mathrm{L}$ hydrochloric acid for several days, with fresh acid replacement once a day until the demineralization was complete. The solution was then rinsed to natural PH with distilled water, and the gelatin was soaked in $0.125 \mathrm{~mol} / \mathrm{L}$ $\mathrm{NaOH}$ for $20 \mathrm{~h}$ to eliminate non-collagenous organic residues and humic acids. Then, samples were rinsed to neutrality again. Samples were gelatinised in $0.001 \mathrm{~mol} / \mathrm{L} \mathrm{HCl}$ at $95^{\circ} \mathrm{C}$ over night and filtered. The resultant residues were freeze-dried to obtain collagen. The collagen samples were weighed in a balance, and the collagen extraction yields are presented in Table 2. The stable isotope ratios for carbon and nitrogen from the resultant $\mathrm{CO}_{2}$ and $\mathrm{N}_{2}$ were measured

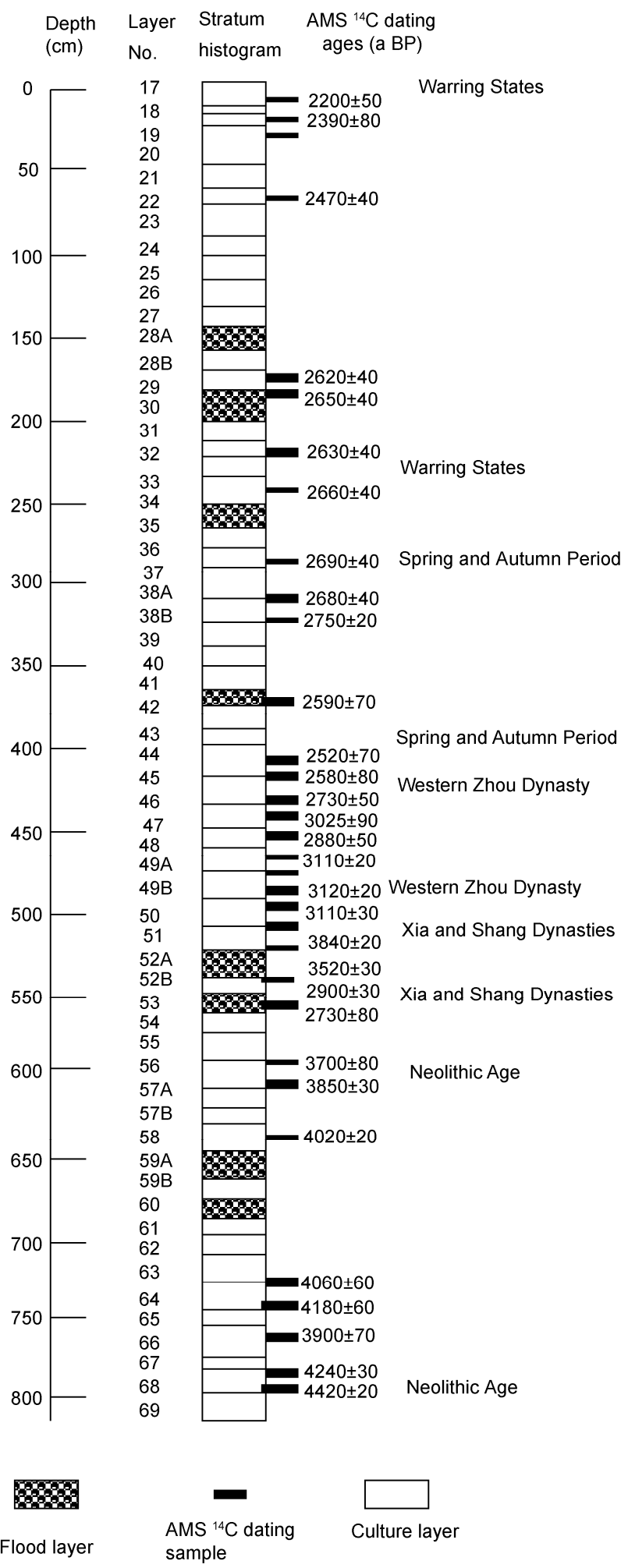

Figure 1 Profile of unit T0202 and ages of the Zhongba site.

on a Delta plus Advantage (produced by Finnigan) isotope ratio mass spectrometer at Key Laboratory of Lake Sediment and Environment, CAS. The $\mathrm{C} / \mathrm{N}$ ratios were determined in a VARIOEL III (produced by Elementar) element analyzer. The isotopic ratios of carbon and nitrogen 
Table 1 AMS ${ }^{14} \mathrm{C}$ dating and its calibrated ages of layers in the excavation unit $\mathrm{T} 0202$ of the Zhongba site

\begin{tabular}{|c|c|c|c|c|c|}
\hline $\mathrm{AMS}^{14} \mathrm{C}$ dating No. & Material & Layer & Yield sample No. & AMS ${ }^{14} \mathrm{C}$ dating ages (a BP) & $\begin{array}{l}\text { Calibrated ages }(\mathrm{OxCal} 3.0) \\
(68.2 \% \text { probability, cal a BP) }\end{array}$ \\
\hline BA01357 & bone & 18 & FCN 0006 & $2380 \pm 70$ & $2470-2310$ \\
\hline BA01361 & bone & 18 & FCN 0104-2 & $2390 \pm 70$ & $2150-2250$ \\
\hline BA01409 & bone & 22 & FCN 0643 & $2430 \pm 60$ & $2430-2510$ \\
\hline BA01362 & bone & 29 & FCN 0981-1 & $2430 \pm 80$ & $2600-2640$ \\
\hline BA01367 & bone & 29 & FCN 1082 & $2450 \pm 60$ & $2610-2690$ \\
\hline BA01419 & bone & 32 & FCN 2094 & $2460 \pm 60$ & $2590-2670$ \\
\hline BA01420 & bone & 33 & FCN 2136 & $2460 \pm 60$ & $2620-2700$ \\
\hline BA01424 & bone & 37 & FCN 2229 & $2480 \pm 80$ & $2660-2720$ \\
\hline BA01368 & bone & $38 b$ & FCN 2219-1 & $2490 \pm 70$ & $2730-2770$ \\
\hline BA01373 & bone & $38 \mathrm{~b}$ & FCN 2275 & $2520 \pm 70$ & $2640-2720$ \\
\hline BA01429 & bone & 43 & FCN 2379 & $2540 \pm 60$ & $2550-2660$ \\
\hline BK2002044 & charcoals & 46 & FCN 2050 & no result & no result \\
\hline BA01374 & bone & 46 & FCN 2513-1 & $2600 \pm 60$ & $2450-2590$ \\
\hline BK2002045 & charcoals & 46 & FCN 2514 & $2640 \pm 60$ & $2680-2780$ \\
\hline BA01380 & bone & 46 & FCN 2527-1 & $2680 \pm 70$ & $2510-2650$ \\
\hline BK2002046 & charcoals & 46 & FCN 2528 & $2730 \pm 80$ & $2985-3065$ \\
\hline BA01433 & bone & 48 & FCN2578 & $2730 \pm 85$ & $2830-2930$ \\
\hline BA01382 & bone & $49 \mathrm{~b}$ & FCN 2613-1 & $2780 \pm 60$ & $3090-3130$ \\
\hline BA01384 & bone & $49 a$ & FCN 2613-3 & $3025 \pm 90$ & $3100-3130$ \\
\hline BA0143 & bone & $49 a$ & FCN2728 & $3100 \pm 60$ & $3080-3140$ \\
\hline BK2002047 & charcoals & 50 & FCN 2658 & $3110 \pm 100$ & $3460-3500$ \\
\hline BA01435 & bone & 50 & FCN 2675 & $3110 \pm 120$ & $3520-3550$ \\
\hline BA01437 & bone & $52 \mathrm{a}$ & FCN 2699 & $3210 \pm 120$ & $2870-2930$ \\
\hline BA01439 & bone & 53 & FCN 2842 & $3240 \pm 100$ & $2730-2810$ \\
\hline BA01390 & bone & 56 & FCN 2958-1 & $3540 \pm 60$ & $3820-3880$ \\
\hline BA01397 & bone & 56 & FCN 2975-4 & $3590 \pm 60$ & $3620-3780$ \\
\hline BA02018 & bone & $58 \mathrm{a}$ & FCN 3142 & $3640 \pm 100$ & $4000-4040$ \\
\hline BK2002048 & charcoals & 64 & FCN 3320 & $3660 \pm 100$ & $4120-4240$ \\
\hline BA02028 & bone & 64 & FCN 3329 & $3800 \pm 70$ & $4000-4120$ \\
\hline BA02030 & bone & $65 \mathrm{~b}$ & FCN 3498 & $3800 \pm 80$ & $3830-3970$ \\
\hline BA01398 & bone & 68 & FCN 3582-1 & $3840 \pm 60$ & $4210-4270$ \\
\hline BA01403 & bone & 68 & FCN 3582-6 & $3880 \pm 90$ & $4400-4440$ \\
\hline
\end{tabular}

are expressed in the standard per mil (\%o) notation as $\delta^{13} \mathrm{C}$ and $\delta^{15} \mathrm{~N}\left(\delta=\left[\left(\mathrm{R}_{\text {sample }} / \mathrm{R}_{\text {standard }}\right)-1\right] \times 1000\right.$, where $\mathrm{R}={ }^{13} \mathrm{C} /{ }^{12} \mathrm{C}$ or ${ }^{15} \mathrm{~N} /{ }^{14} \mathrm{~N}$ ) relative to the international standards $\mathrm{V}-\mathrm{PDB}$ and $\mathrm{N}_{2}$, respectively. The results are shown in Table 2 and Figure 2.

\subsection{Statistical analyses}

Statistical analyses were conducted with SPSS 11.0 software. We used $t$-tests to determine whether the differences in mean values between two species were significant. If the probability value was larger than the hypothesized value 0.05 , the differences in mean values between the two groups were significant [23].

\section{Explanation and discussion}

\subsection{The preservation quality of bone}

$\mathrm{C} / \mathrm{N}$ rations are an important indicator of bone preservation quality, with an acceptable value of well preserved collagen ranging from 2.9 to 3.6. Furthermore, the $\mathrm{C} / \mathrm{N}$ rations of fresh bone collagen of the modern animals fall in this same range [24]. Collagen samples with $\mathrm{C} / \mathrm{N}$ values outside this range are probably due to contamination, or to the loss of collagen $\mathrm{C}$ and $\mathrm{N}$ isotopes to the surrounding environment

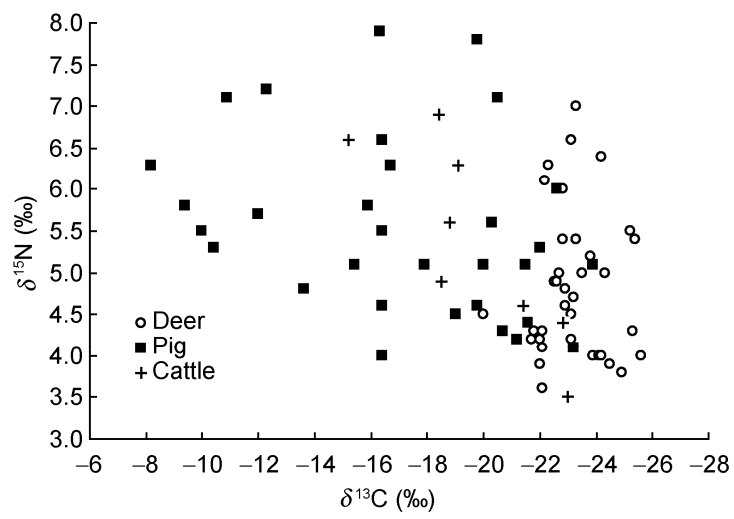

Figure $2 \delta^{13} \mathrm{C}$ and $\delta^{15} \mathrm{~N}$ values of animal bone collagen. 
Table 2 Collagen extraction yields and collagen $\delta^{13} \mathrm{C}$ and $\delta^{15} \mathrm{~N}$ values of animal bones in the layers of the Zhongba site ${ }^{\text {a) }}$

\begin{tabular}{|c|c|c|c|c|c|c|c|c|}
\hline Layer & No. & Animal & $\delta^{13} \mathrm{C}(\%)$ & $\delta^{15} \mathrm{~N}(\%)$ & $\mathrm{C} \%$ & $\mathrm{~N} \%$ & $\mathrm{C}: \mathrm{N}$ & Collagen extraction yields $\left(\mathrm{mg} \mathrm{g}^{-1}\right)$ \\
\hline 18 & $104 a$ & deer (left scapula) & -24.2 & 2.8 & 11.1 & 3.7 & 3.4 & 4.2 \\
\hline 18 & $104 b$ & deer (left scapula) & -23.8 & 5.1 & 6.0 & 1.8 & 3.7 & 21.4 \\
\hline 19 & $112 \mathrm{a}$ & deer (right scapula) & -23.9 & 4.0 & 22.1 & 7.9 & 3.2 & 19.1 \\
\hline 20 & 296 & deer (left scapula) & -25.6 & 4.0 & 21.4 & 7.6 & 3.2 & 20.7 \\
\hline 22 & $643 a$ & deer (humerus) & -23.1 & 4.2 & 11.2 & 4.0 & 3.2 & 23.3 \\
\hline 22 & $643 b$ & deer (humerus) & -23.1 & 4.2 & 16.8 & 6.0 & 3.2 & 8.4 \\
\hline 22 & $643 \mathrm{c}$ & deer (femur) & -22.9 & 4.8 & 23.8 & 8.4 & 3.2 & 79.3 \\
\hline 22 & $643 \mathrm{~d}$ & deer (metacarpus) & -22.7 & 5.0 & 13.7 & 4.9 & 3.2 & 10.9 \\
\hline 22 & $643 \mathrm{e}$ & deer (femur) & -22.6 & 4.9 & 20.2 & 7.4 & 3.1 & 4.1 \\
\hline 23 & 715 & deer (left scapula) & -22.0 & 3.9 & 27.7 & 9.8 & 3.2 & 19.2 \\
\hline 25 & 809 & deer (left scapula) & -24.9 & 3.8 & 31.5 & 11.4 & 3.2 & 16.8 \\
\hline 27 & 909 & deer (right tibia) & -25.2 & 5.5 & 20.1 & 7.1 & 3.2 & 20.6 \\
\hline 27 & 912 & deer (left scapula) & -22.5 & 4.9 & 30.9 & 11.2 & 3.2 & 64.5 \\
\hline $28 \mathrm{~b}$ & 975 & deer (left radius) & -24.8 & 3.7 & 5.2 & 1.7 & 3.5 & 4.6 \\
\hline 29 & 981 & deer (scapula) & -23.5 & 5.0 & 26.1 & 9.5 & 3.2 & 46.8 \\
\hline 31 & 2082 & deer (left tibia) & -23.0 & 3.5 & 18.6 & 6.6 & 3.2 & 7.1 \\
\hline 32 & $2094 a$ & deer (scapula) & -22.1 & 3.6 & 31.4 & 11.1 & 3.2 & 33.2 \\
\hline 33 & $2016 \mathrm{a}$ & deer (hipbone) & -22.1 & 4.3 & 21.7 & 7.9 & 3.2 & 23.4 \\
\hline 33 & $2016 b$ & deer (radius) & -22.0 & 2.3 & 0.9 & 0.2 & 4.8 & 55.3 \\
\hline 33 & $2136 a$ & deer (phalanx) & -24.1 & 4.0 & 32.3 & 11.5 & 3.2 & 41.4 \\
\hline 33 & $2136 b$ & deer (radius) & -19.7 & 4.7 & 13.6 & 4.4 & 3.6 & 34.8 \\
\hline 33 & $2136 c$ & deer (phalanx) & -25.3 & 4.3 & 28.7 & 10.3 & 3.2 & 10.5 \\
\hline 33 & $2136 \mathrm{~d}$ & deer (tibia) & -22.3 & 6.3 & 29.7 & 10.5 & 3.2 & 23.2 \\
\hline 34 & $2151 \mathrm{a}$ & deer (right calcaneus) & -22.8 & 5.4 & 19.5 & 7.1 & 3.2 & 34.1 \\
\hline 34 & 2128 & deer (hipbone) & -20.0 & 4.5 & 24.1 & 8.7 & 3.2 & 23.4 \\
\hline 34 & $2151 b$ & deer (phalanx) & -22.9 & 4.6 & 21.8 & 7.8 & 3.2 & 44.7 \\
\hline 36 & $2225 \mathrm{a}$ & deer (right humerus) & -22.0 & 5.3 & 33.2 & 11.9 & 3.2 & 27.9 \\
\hline $38 \mathrm{a}$ & 2244 & deer (hipbone) & -23.1 & 4.5 & 27.5 & 10.0 & 3.2 & 45.5 \\
\hline $38 \mathrm{~b}$ & 2219 & deer (phalanx) & -21.8 & 4.3 & 26.4 & 9.5 & 3.2 & 20.9 \\
\hline 40 & $2316 \mathrm{~g}$ & deer (right tibia) & -23.1 & 6.6 & 18.7 & 6.6 & 3.2 & 32.3 \\
\hline 42 & $2345 \mathrm{a}$ & deer (metacarpus) & -24.3 & 5.0 & 28.7 & 10.5 & 3.1 & 28.7 \\
\hline 42 & $2345 b$ & deer (left humerus) & -23.3 & 7.0 & 29.1 & 10.3 & 3.2 & 33.4 \\
\hline 43 & $2379 a$ & deer (radius) & -25.4 & 5.4 & 22.5 & 8.1 & 3.2 & 59.2 \\
\hline 43 & $2379 b$ & deer (talus) & -22.0 & 4.2 & 29.2 & 10.5 & 3.2 & 41.1 \\
\hline 45 & 2053 & deer (radius) & -22.1 & 4.1 & 30.6 & 10.7 & 3.3 & 53.2 \\
\hline 46 & 2513 & deer (femur) & -23.2 & 4.7 & 33.0 & 11.7 & 3.2 & 18.2 \\
\hline 46 & $2527 \mathrm{a}$ & deer (metacarpus) & -22.8 & 6.0 & 17.1 & 6.1 & 3.2 & 77.1 \\
\hline 47 & 2563 & deer (right tibia) & -24.2 & 6.4 & 25.8 & 9.0 & 3.3 & 16.6 \\
\hline 48 & 2578 & deer (cervical vertebra) & -23.1 & 3.4 & 2.7 & 0.6 & 4.6 & 6.2 \\
\hline 50 & $2645 \mathrm{c}$ & deer (right tibia) & -24.5 & 3.9 & 20.8 & 7.6 & 3.1 & 50 \\
\hline 50 & 2642 & deer (humerus) & -23.3 & 5.4 & 14.9 & 5.4 & 3.2 & 70 \\
\hline 50 & $2679 a$ & deer (scapula) & -23.8 & 5.2 & 14.8 & 5.2 & 3.2 & 56.5 \\
\hline 50 & $2679 b$ & deer (tibia) & -22.6 & 4.9 & 6.8 & 2.2 & 3.5 & 7.7 \\
\hline $51 \mathrm{~b}$ & 2735 & deer (left hipbone) & -26.0 & 4.6 & 9.6 & 3.3 & 3.3 & 22.1 \\
\hline $52 \mathrm{a}$ & 2914 & deer (scapula) & -21.7 & 4.2 & 27.6 & 9.8 & 3.2 & 21.7 \\
\hline $55 \mathrm{~b}$ & 2942 & deer (cervical vertebra) & -22.2 & 6.1 & 31.7 & 11.4 & 3.2 & 76.3 \\
\hline 60 & 3211 & deer (right tibia) & -22.6 & 5.0 & 9.8 & 3.4 & 3.3 & 11.2 \\
\hline 63 & 3298d & deer (left talus) & -23.4 & 6.2 & 1.3 & 0.7 & 2.2 & 6.1 \\
\hline 64 & $3329 \mathrm{c}$ & deer (hipbone) & -24.2 & 4.0 & 15.7 & 5.9 & 3.1 & 36.7 \\
\hline
\end{tabular}


(Continued)

\begin{tabular}{|c|c|c|c|c|c|c|c|c|}
\hline 67 & 3559 & deer (scapula) & -23.5 & 1.7 & 1.1 & 0.2 & 5.2 & 17.4 \\
\hline 68 & $3582 c$ & deer (scapula) & -19.8 & 4.9 & 7.6 & 2.6 & 3.3 & 15.1 \\
\hline 18 & $104 \mathrm{c}$ & pig (humerus) & -21.4 & 2.9 & 2.1 & 0.7 & 3.5 & 32 \\
\hline 18 & 104d & pig (calcaneus) & -16.4 & 1.8 & 0.8 & 0.1 & 5.1 & 72 \\
\hline 19 & $112 b$ & pig (humerus) & -21.2 & 4.2 & 34.7 & 12.0 & 3.3 & 41.4 \\
\hline 19 & $112 \mathrm{c}$ & pig (mandible) & -16.3 & 7.9 & 54.7 & 19.2 & 3.3 & 27.7 \\
\hline 21 & $492 \mathrm{a}$ & pig (scapula) & -22.0 & 5.3 & 17.6 & 6.2 & 3.2 & 13.8 \\
\hline 21 & $492 b$ & pig (humerus) & -20.5 & 7.1 & 27.7 & 9.9 & 3.2 & 54.8 \\
\hline 22 & $643 f$ & pig (metacarpus) & -22.1 & 1.8 & 1.5 & 0.4 & 3.8 & 30.3 \\
\hline 26 & $869 \mathrm{a}$ & pig (hipbone) & -23.9 & 5.1 & 21.5 & 7.5 & 3.3 & 60.5 \\
\hline 26 & $869 b$ & pig (calcaneus) & -21.5 & 3.8 & 2.9 & 0.8 & 4.1 & 77.3 \\
\hline 29 & $981 \mathrm{~b}$ & pig (phalanx) & -19.8 & 7.8 & 23.8 & 7.8 & 3.5 & 19.5 \\
\hline 31 & 2073 & pig (vertebra) & -21.5 & 5.1 & 20.4 & 7.4 & 3.2 & 46 \\
\hline 33 & $2136 \mathrm{e}$ & pig (vertebra) & -20.7 & 4.3 & 34.9 & 12.2 & 3.3 & 31.2 \\
\hline 36 & $2225 b$ & pig (ulna) & -12.0 & 5.7 & 17.9 & 6.4 & 3.2 & 16 \\
\hline $38 \mathrm{~b}$ & $2219 a$ & pig (calcaneus) & -19.8 & 4.6 & 14.4 & 5.1 & 3.2 & 10.9 \\
\hline $38 \mathrm{~b}$ & $2219 b$ & pig (humerus) & -21.6 & 4.4 & 27.4 & 9.8 & 3.2 & 87.4 \\
\hline $38 \mathrm{~b}$ & $2219 c$ & pig (humerus) & -20.3 & 5.6 & 30.9 & 11.0 & 3.2 & 20.6 \\
\hline 46 & $2527 \mathrm{~b}$ & pig (calcaneus) & -12.3 & 7.2 & 31.5 & 10.9 & 3.3 & 47.2 \\
\hline 46 & $2527 \mathrm{c}$ & pig (vertebra) & -10.9 & 7.1 & 22.4 & 8.1 & 3.2 & 78.4 \\
\hline 50 & $2645 a$ & pig (tibia) & -16.4 & 4.6 & 21.3 & 7.6 & 3.2 & 58.1 \\
\hline 50 & $2645 b$ & pig (scapula) & -17.9 & 5.1 & 12.5 & 4.4 & 3.2 & 51.5 \\
\hline $52 a$ & 2699a & pig (hipbone) & -22.5 & 11.8 & 0.8 & 0.6 & 1.5 & 2.7 \\
\hline 53 & $2842 b$ & pig (tibia) & -21.0 & 7.0 & 3.8 & 1.3 & 3.3 & 44.9 \\
\hline 53 & $2842 c$ & pig (radius) & -16.4 & 6.6 & 25.3 & 9.0 & 3.2 & 53.4 \\
\hline 56 & 2975 & pig (ulna) & -15.4 & 5.1 & 16.9 & 6.0 & 3.2 & 35.4 \\
\hline 58 & $3142 \mathrm{a}$ & pig (hipbone) & -9.4 & 5.8 & 16.5 & 5.8 & 3.2 & 60.2 \\
\hline 58 & $3142 b$ & pig (tibia) & -19.0 & 4.5 & 17.0 & 6.2 & 3.2 & 38.4 \\
\hline 62 & $3487 \mathrm{a}$ & pig (metacarpus) & -20.0 & 5.1 & 18.2 & 6.6 & 3.1 & 34.4 \\
\hline 62 & $3487 \mathrm{~b}$ & pig (humerus) & -10.0 & 5.5 & 19.5 & 7.0 & 3.2 & 51.8 \\
\hline 62 & 3265 & pig (radius) & -18.9 & 5.8 & 3.0 & 0.9 & 3.6 & 36.6 \\
\hline 62 & $3487 \mathrm{c}$ & pig (femur) & -8.2 & 6.3 & 39.2 & 14.0 & 3.2 & 30.7 \\
\hline 63 & $3298 \mathrm{a}$ & pig (maxilla) & -16.7 & 6.3 & 19.8 & 7.1 & 3.2 & 59 \\
\hline 63 & $3298 b$ & pig (humerus) & -16.4 & 5.5 & 18.3 & 6.5 & 3.2 & 71.1 \\
\hline 63 & $3298 \mathrm{c}$ & pig (ulna) & -23.2 & 4.1 & 23.8 & 8.5 & 3.2 & 7.8 \\
\hline 64 & 3329a & pig (ulna) & -13.1 & 6.1 & 12.3 & 4.5 & 3.1 & 8.6 \\
\hline 64 & $3329 b$ & pig (radius) & -10.4 & 5.3 & 16.9 & 6.3 & 3.1 & 37.2 \\
\hline 65 & $3456 a$ & pig (talus) & -13.6 & 4.8 & 14.0 & 5.3 & 3.0 & 85 \\
\hline 65 & $3456 b$ & pig (vertebra) & -22.6 & 6.0 & 14.3 & 5.1 & 3.2 & 27.6 \\
\hline 65 & $3456 \mathrm{f}$ & pig (talus) & -14.2 & 5.6 & 5.2 & 2.2 & 2.7 & 27.9 \\
\hline 65 & $3456 \mathrm{~g}$ & pig (femur) & -15.9 & 5.8 & 33.9 & 12.0 & 3.2 & 32.8 \\
\hline 65 & $2472 \mathrm{a}$ & pig (humerus) & -16.4 & 4.0 & 19.9 & 7.4 & 3.1 & 18 \\
\hline 65 & $2472 b$ & pig (calcaneus) & -17.9 & 6.7 & 3.3 & 1.6 & 2.3 & 4.4 \\
\hline 30 & $2016 c$ & cattle (rib) & -23.0 & 3.5 & 18.6 & 6.6 & 3.2 & 41.9 \\
\hline 50 & $2679 c$ & cattle (carpus) & -18.8 & 5.6 & 13.9 & 5.1 & 3.1 & 70.3 \\
\hline $52 a$ & $2699 b$ & cattle (talus) & -20.3 & 4.6 & 2.4 & 0.8 & 3.3 & 40.8 \\
\hline $52 a$ & $2699 c$ & cattle (scapula) & -20.2 & 5.4 & 4.9 & 1.7 & 3.3 & 13.2 \\
\hline 53 & $2842 \mathrm{a}$ & cattle (tarsus) & -22.8 & 4.4 & 18.3 & 6.5 & 3.2 & 35 \\
\hline 56 & $2958 \mathrm{a}$ & cattle (scapula) & -21.4 & 4.6 & 14.1 & 5.1 & 3.2 & 81.8 \\
\hline 56 & $2958 b$ & cattle (carpus) & -20.1 & 4.1 & 8.3 & 3.0 & 3.2 & 20.9 \\
\hline
\end{tabular}


a) The boldface means the sample has been contaminated.

[25]. Another important criterion to estimate collagen preservation is whether the $\mathrm{C}$ and $\mathrm{N}$ mass contents of collagen account for over $13.0 \%$ and $4.8 \%$, respectively [24]. Based on these criteria, we found 11 contaminated pig bones, and 11 contaminated deer bones. For pigs and cattle, 31 out of 41 samples and 8 out of 14 samples were well preserved, respectively. Sample preservation results are shown in Table 2, with bolded samples indicating contaminated bone collagen. Overall, the animal bones of the Zhongba site were well preserved and over $50 \%$ of the isotopic analyses were conducted successfully. However, several samples of each kind of animal were found to be contaminated. Generally, bones from a cold and arid area can be well preserved, but there were high temperatures and humidity in the Zhongba area. Even so, animal samples from the Zhongba site also can be well preserved possibly due to the muscles and guts having been peeled off the skeletons by humans.

Another important issue that should be taken into account is whether the loss of bone collagen has changed the pristine biological isotopic information. Beside the contaminated bone samples, the collagen extraction yielded a wide range with a maximum of $87.4 \mathrm{mg} \mathrm{g}^{-1}$, and a minimum of $4.1 \mathrm{mg} \mathrm{g}^{-1}$. The mean was $38.4 \mathrm{mg} \mathrm{g}^{-1}$, and the standard deviation was $21.29 \mathrm{mg} \mathrm{g}^{-1}$. In addition, the samples from the same layer also had wide ranges in collagen extraction yields. Figure 3 shows the bone collagen extraction yields for Zhongba deer, cattle and pigs [26].

\subsection{Carbon isotope explanation}

The mean $\delta^{13} \mathrm{C}$ values of deer, cattle and pigs were $-23.1 \%$, $-19.6 \%$ and $-17.1 \%$, respectively, and the differences in mean $\delta^{13} \mathrm{C}$ values between deer and cattle, deer and pigs and cattle and pigs were all significant (Student's $t$-test, $P<$ $0.01)$. This means that there were differences in food sources among the animals. Given that animals will enrich by $5 \%$ o their tissue $\delta^{13} \mathrm{C}$ value over their food source, the food consumed by deer, cattle and pigs likely had mean $\delta^{13} \mathrm{C}$ values of $-28.1 \%$ o, $-24.6 \%$ and $-22.1 \%$, respectively. The $\delta^{13} \mathrm{C}$ values of deer ranged from $-25.6 \%$ to $-20.0 \%$, and the corresponding $\delta^{13} \mathrm{C}$ values of plants consumed by deer ranged from $-30.6 \%$ o to $-25.0 \%$, indicating that deer subsisted in closed habitats and fed only on $\mathrm{C}_{3}$ plants. The possible reason why these plants have such negative $\delta^{13} \mathrm{C}$ values is the canopy effect of forests [27]. In addition, the $\delta^{13} \mathrm{C}$ values of cattle ranged from $-23.0 \%$ to $-15.2 \%$, and
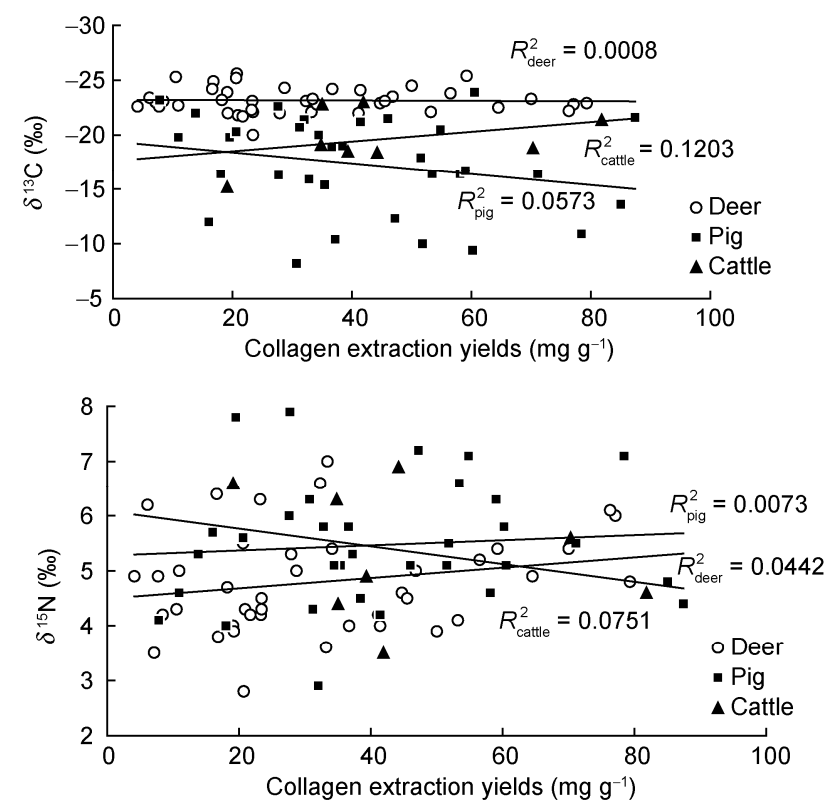

Figure $3 \delta^{13} \mathrm{C}, \delta^{15} \mathrm{~N}$ values of bone collagen plotted as a function of collagen extraction yields.

the corresponding $\delta^{13} \mathrm{C}$ values of plants they consumed likely ranged from $-28.0 \%$ o to $-20.2 \%$, indicating that cattle also ate only $\mathrm{C}_{3}$ plants. The fact that mean $\delta^{13} \mathrm{C}$ values of cattle were more positive than those of deer suggests that the former lived in open habitats. We can conclude from Figure 4 that the standard deviation of deer values was the smallest $(1.18 \%$ ) , demonstrating that the food sources of deer were similar. Cattle had a larger standard deviation of $\delta^{13} \mathrm{C}$ values than that of the deer. Hence, they had a wider food source range than deer. The omnivorous pigs had a considerably large standard deviation (up to $4.46 \%$ ), with $\delta^{13} \mathrm{C}$ values ranging from $-23.9 \%$ to $-8.2 \%$. The corresponding likely $\delta^{13} \mathrm{C}$ values of food consumed by pigs ranged from $-28.9 \%$ o to $-13.2 \%$, indicating that the diets of pigs ranged from $\mathrm{C}_{4}$-dominated plants to only $\mathrm{C}_{3}$ plants. The clear differences in pig food and $\mathrm{C}_{3}$ food content percentages at the Zhongba site may be the results of different pig breeding strategies [28]. At that time, the Zhongba economy was based on salt produced rather than agriculture or animal husbandry [22]. The ancient people in the Zhongba area exchanged salt for food, such as pigs. This means that it is feasible that pigs trading was carried out in 


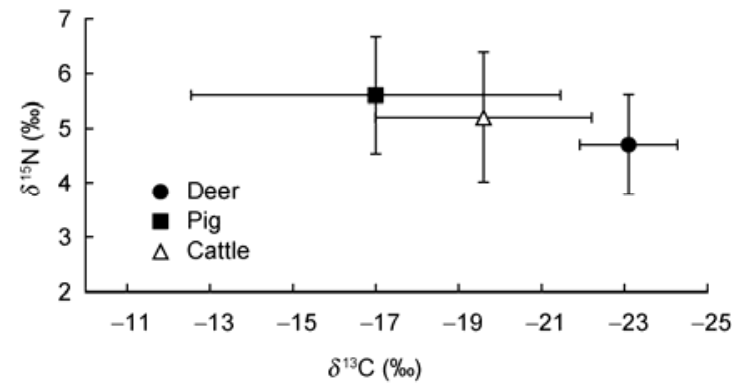

Figure 4 Means and standard deviations $(2 \sigma)$ for $\delta^{13} \mathrm{C}$ and $\delta^{15} \mathrm{~N}$ values of animal bone collagen.

China from about 4000 years ago $[29,30]$.

\subsection{Nitrogen isotope explanation}

The mean $\delta^{15} \mathrm{~N}$ values of deer, cattle and pigs were $4.7 \%$, $5.2 \% 0$ and $5.5 \%$, respectively, and the differences in mean $\delta^{15} \mathrm{~N}$ values between deer and cattle, deer and pigs and cattle and pigs were all significant (Student's $t$-test, $P<0.01$ ). The mean $\delta^{15} \mathrm{~N}$ value of deer was more negative than that of cattle. This is because deer fed on foliage and shrubs in closed habitats and cattle fed on grasses in open habitats, and foliage and shrubs have more negative $\delta^{15} \mathrm{~N}$ values than grasses [30]. Pigs often ate leftovers of ancient peoples, which therefore would have included offal of deer and cattle $[31,32]$. Thus, pigs lived at a higher trophic level and had more positive $\delta^{15} \mathrm{~N}$ values than cattle and deer, as seen in their nitrogen isotope enrichment. However, the differences among pigs, cattle and deer were less than a trophic level difference of 3.0\%o, hence the diets of these particular pigs probably did not included much animal meat. The $\delta^{15} \mathrm{~N}$ values of herbivorous cattle and deer are close to those of modern European herbivores, and are markedly different from those of modern African herbivores. This indicates that the moisture in the atmosphere in the ancient Zhongba area was similar to that of modern Europe, but different to that of modern Africa [33].

\subsection{Palaeoclimate and palaeoenviroment}

Generally speaking, the chemical and physical indices from site were disturbed by human activities and can not fully reflect environmental evolution. However, the bone collagen $\delta^{13} \mathrm{C}$ and $\delta^{15} \mathrm{~N}$ of wild herbivore mammals can be used as indices of palaeoclimate and palaeoenvironment for the reasons mentioned above $[34,35]$. Most cattle samples in the Zhongba layers have not been analyzed in this study. Thus, the sample number of cattle bone collagen is not statistically robust because of the limited cattle samples. However, a high number of deer bone collagen samples were analyzed. Thus, we selected deer bone collagen $\delta^{13} \mathrm{C}$ and $\delta^{15} \mathrm{~N}$ as environmental indices to reconstruct palaeoclimate and palaeoenvironment of the Zhongba area. In order to study the environment of different ages in this area, unit T0202 was initially divided into three phases: Phase I, Phase II and Phase III based on $\mathrm{AMS}^{14} \mathrm{C}$ dating and archaeology (layers containing contaminated bone samples excluded). Phase I comprised levels 50-64 and dated to approximately 3500-4200 a BP (the Xia Dynasty, early Neolithic Age). Phase II included levels 34-49 and dated to approximately 2800-3500 a BP (the Western Zhou Dynasty). Lastly, Phase III included levels 18-33 and dated to approximately 2200-2800 a BP (the Warring States and Spring and Autumn Periods). Table 3 shows the descriptive statistics of deer collagen $\delta^{13} \mathrm{C}$ and $\delta^{15} \mathrm{~N}$ values of the different periods. Figure 5 shows the stratigraphic and temporal variation of collagen $\delta^{13} \mathrm{C}$ and $\delta^{15} \mathrm{~N}$ values for deer. Herbivore bone collagen $\delta^{13} \mathrm{C}$ values related to the corresponding eaten plant $\delta^{13} \mathrm{C}$ values, and the plant $\delta^{13} \mathrm{C}$ values related to climate and forest canopy closure. A temperature decrease, a precipitation increase and a closed canopy caused more negative plant ${ }^{13} \mathrm{C}$ values [36]. The $t$-tests showed that there were no differences in collagen $\delta^{13} \mathrm{C}$ between Phase I and Phase II, Phase II and Phase III, Phase I and Phase III (Student's $t$-test, $P<0.05)$. This indicates that the climate, temperature and

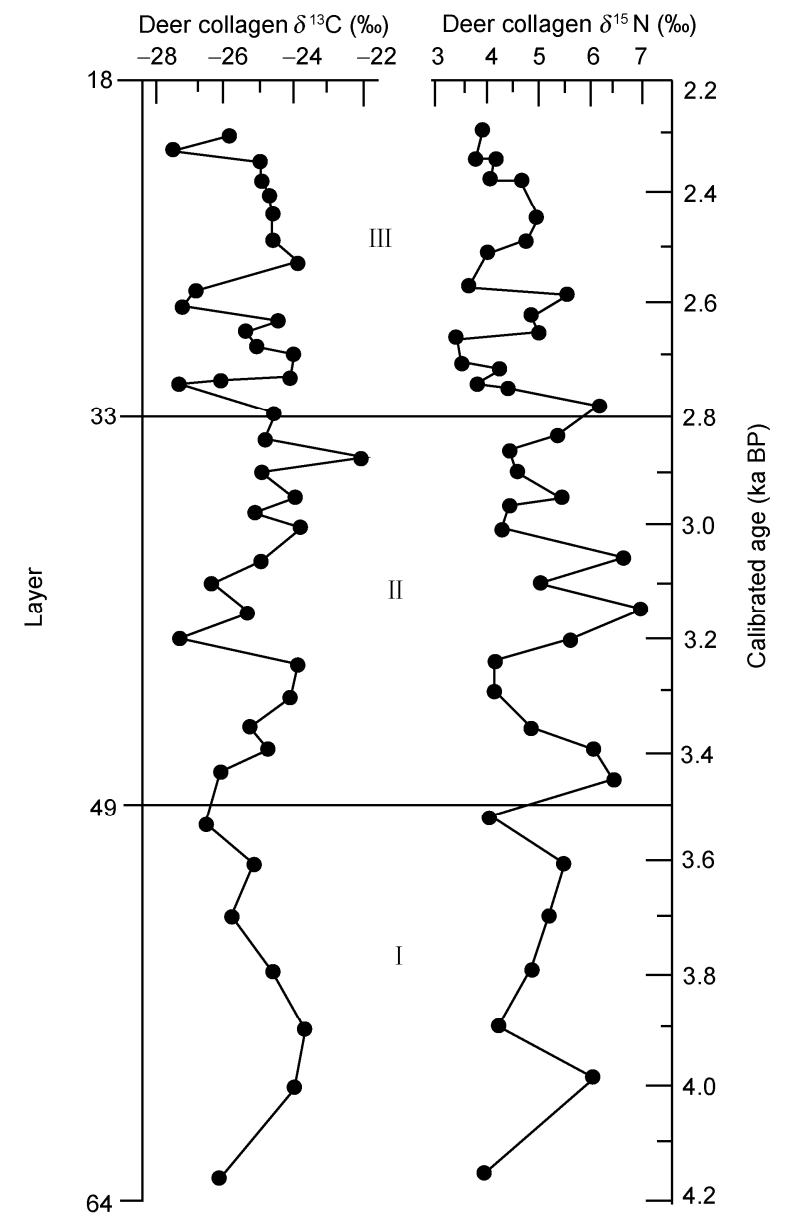

Figure 5 Stratigraphic variation of collagen $\delta^{13} \mathrm{C}$ and $\delta^{15} \mathrm{~N}$ values for deer. 
Table 3 The descriptive statistics of deer collagen $\delta^{13} \mathrm{C}$ and $\delta^{15} \mathrm{~N}$ values of different periods

\begin{tabular}{ccccccc}
\hline $\begin{array}{c}\text { Isotope } \delta \\
\text { value }\end{array}$ & Period & $\begin{array}{c}\mathrm{N} \text { (Sample } \\
\text { number) }\end{array}$ & Minimum Maximum & $\begin{array}{c}\text { Mean } \\
\text { value }\end{array}$ & $\begin{array}{c}\text { Standard } \\
\text { deviation }\end{array}$ \\
\hline \multirow{3}{*}{$\delta^{13} \mathrm{C}$} & I & 7 & -24.5 & -21.7 & -23.2 & 1.0 \\
& II & 15 & -25.4 & -20.0 & -22.8 & 1.2 \\
& III & 18 & -25.6 & -22.0 & -23.3 & 1.3 \\
\hline \multirow{3}{*}{$\delta^{15} \mathrm{~N}$} & I & 7 & 3.9 & 6.1 & 4.8 & 0.8 \\
& II & 15 & 4.1 & 7.0 & 5.2 & 0.9 \\
& III & 18 & 3.5 & 6.3 & 4.5 & 0.7 \\
\hline
\end{tabular}

vegetation were relatively stable from 2200 to 4200 a BP. The plant $\delta^{13} \mathrm{C}$ signals were passed on to herbivore bone collagen through the food web. Plants in warmer and drier areas have more positive $\delta^{15} \mathrm{~N}$ values. Thus, bone collagens of herbivores living in warmer and drier habitats consequently have more positive $\delta^{15} \mathrm{~N}$ values [37]. Similarly, the $t$-tests showed that there were no differences in collagen $\delta^{15} \mathrm{~N}$ between Phase I and Phase II, Phase II and Phase III, Phase I and Phase III (Student's $t$-test, $P<0.05$ ). This indicates that there were no large oscillations in relative humidity and temperature from 2200 to 4200 a BP. Pollen analysis for this area shows that the predominant pollen of trees and shrubs were high, and the pollen of aquatic herbs, ferns, Gramineae and Raununculaceae also were high between $3200 \mathrm{BC}$ and $500 \mathrm{BC}$. This indicates that it was warm and moist, and that there was no large oscillation in climate during this period [38]. The Zhongba site belongs to the middle subtropics, and is in the valley of the upper course of the Yangtze River. In addition, the Daba Mountains and the Wushan Mountains are situated northwest and southeast of the study area, respectively. Thus, the influence of low temperature is not clear in the Zhongba area [39]. The two environmental proxies of collagen $\delta^{13} \mathrm{C}$ and $\delta^{15} \mathrm{~N}$ together indicate that the ecology, climate and vegetation in the area were relatively stable from 2200 to 4200 a BP, which may be responsible for the thickest and most complete cultural layers observed in the Zhongba area.

\subsection{Minimum sample number}

Generally, the animal fossils in one site are not large in number, and the usable number often decreases after the fossils have been prepared. Thus, it is important to determine if enough samples have been collected to allow reconstruction of palaeodiets using $\mathrm{C}$ and $\mathrm{N}$ isotopic ratios. Thus, studies on the minimum sample number bear a certain meaning in environmental archaeology. For example, given the standard deviation of 1.18 , at least 9 samples should be analyzed to estimate the mean $\delta^{13} \mathrm{C}$ value of deer within $1 \%$ o with $95 \%$ confidence (not including the contaminated samples). As shown in Table 4, the minimum sample numbers need to obtain mean $\delta^{13} \mathrm{C}$ and $\delta^{15} \mathrm{~N}$ values of deer, cattle and pigs within $1 \%$ with $95 \%$ confidence can be suggested based on the fossil collagen standard deviations of $\delta^{13} \mathrm{C}$ and $\delta^{15} \mathrm{~N}$ [40]. Because of the wide range of standard deviations
Table 4 Minimum sample numbers substituting mean $\delta^{13} \mathrm{C}$ and $\delta^{15} \mathrm{~N}$ values of deer, cattle and pigs

\begin{tabular}{cccc}
\hline Isotope & Deer & Pigs & Cattle \\
\hline $\mathrm{SD}\left(\delta^{13} \mathrm{C}\right)$ & 1.18 & 4.46 & 2.61 \\
$\delta^{13} \mathrm{C}$ minimum number $(95 \%$ confidence $)$ & 8 & 73 & 16 \\
\hline $\mathrm{SD}\left(\delta^{15} \mathrm{~N}\right)$ & 0.91 & 1.07 & 1.19 \\
$\delta^{15} \mathrm{~N}$ minimum number $(95 \%$ confidence $)$ & 4 & 5 & 6 \\
\hline
\end{tabular}

of $\delta^{13} \mathrm{C}$, the corresponding minimum sample numbers of pigs and cattle are 73 and 16, respectively. Thus, the valid samples of pigs (number $=31)$ and cattle $($ number $=8)$ were not sufficient for calculating mean $\delta^{13} \mathrm{C}$ values in this study. However, valid sample numbers of deer were sufficient to calculate mean $\delta^{13} \mathrm{C}$ and $\delta^{15} \mathrm{~N}$ values.

\section{Conclusions}

Information on palaeodiets, palaeoclimate, palaeoecology and human activities was extracted based on carbon and nitrogen stable isotope ratio analyses of deer, cattle and pig bone collagen from the Zhongba site in the Three Gorges Reservoir region of the Yangtze River. The main conclusions are as follows:

(1) Most mammal fossil bone collagen from the Zhongba site was well preserved and not contaminated. The loss of bone collagen did not alter the original information that could be derived from the biological isotopes.

(2) Both deer and cattle fed only on $\mathrm{C}_{3}$ plants, indicating that they subsisted in the same ecosystem, but utilized different niches. Deer inhabited closed forests and cattle inhabited open areas. Thus, deer had more negative $\delta^{13} \mathrm{C}$ values because of canopy effects. $\delta^{13} \mathrm{C}$ values of pigs ranged widely from $-23.9 \%$ to $-8.2 \%$, and the corresponding plants consumed were estimated to have carbon isotopic signatures of $-28.9 \%$ o to $-13.2 \%$. The diets among pigs were very different, which may be a result of the fact that pigs were brought to the site from other places by trading in stead of them having been reared locally. The mean $\delta^{15} \mathrm{~N}$ value of deer was more negative than that of cattle, because $\delta^{15} \mathrm{~N}$ foliage and shrubs eaten by deer were more negative than those of herbaceous plants eaten by cattle. The diets of pigs included deer and cattle, and thus lived at a higher trophic level, which is the likely reason for the more positive $\delta^{15} \mathrm{~N}$ values of pig than those of deer and cattle.

(3) The results of bone collagen carbon and nitrogen isotope analyses show that the differences in deer $\delta^{13} \mathrm{C}$ and $\delta^{15} \mathrm{~N}$ among different archaeological periods were not significant. This indicates that there were no large oscillations in climate, environment or ecology from 2200 to 4200 a BP, which explains well the complete cultural layers found at the Zhongba site.

(4) The minimum samples that can estimate mean $\delta^{13} \mathrm{C}$ values within $1 \%$ with $95 \%$ confidence based on standard deviation of $\delta^{13} \mathrm{C}$ are 8,73 and 16 for deer, pigs and cattle, 
respectively, in the Zhongba area, and 4, 5 and 6 for mean $\delta^{15} \mathrm{~N}$ values of deer, pigs and cattle, respectively.

The authors would like to thank Wang Fubao and Ma Chunmei from Nanjing University and anonymous referees for their helpful comments on the paper. This work was supported by the National Natural Science Foundation of China (40971115), the University Doctoral Foundation (20090091110036), the Open Foundation of the State Key Laboratory of Loess and Quaternary Geology from the Institute of Earth Environment, CAS (SKLLQG0817), the Test Foundation of Modern Analyses Center of Nanjing University (0209001309) and the Foundation of the Ministry of Science and Technology of the People's Republic of China (2010BAK67B02).

1 Drucker D, Bocherens H. Carbon and nitrogen stable isotopes as tracers of change in diet breadth during middle and upper palaeolithic in Europe. Int J Ost, 2004, 14: 162-177

2 Ambrose S H. Preparation and characterization of bone and tooth collagen for isotopic analysis. J Archaeol Sci, 1990, 17: 431-451

3 Vogel J C, Van der merwe N J. Isotopic evidence for early maize cultivation in New York state, American. Antiquity, 1977, 42: 238-242

4 Deniro M J. Postmortem preservation and alteration of in vivo bone collagen isotope ratios in relation to paleodietary reconstruction. $\mathrm{Na}$ ture, 1985, 317: 806-809

5 Hobson K A, Schwarcz H P. The variation in ${ }^{13} \mathrm{C}$ values in bone collagen for two wild herbivore populations: Implications for palaeodiet studies. J Archaeol Sci, 1986, 13: 101-106

6 Iacumin P, Bocherens H, Delgado H A, et al. Stable isotope study of fossil mammal remains from the Paglicci cave, Southern Italy $\mathrm{N}$ and C as palaeoenvironmental indicators. Earth Planet Sci Lett, 1997, 148: 349-357

7 Robert E M, Rhiannon E S, Michael P R. Bone as a stable isotope archive for local climatic information. Quat Sci Rev, 2004, 23: 959-965

8 Stanley H A, Jane B, Harold W K. Status and gender differences in diet at Mound 72, Cahokia, revealed by isotopic analysis of bone. $\mathrm{J}$ Ant Archaeol, 2003, 22: 217-226

9 Cai L Z, Qiu S H. ${ }^{13} \mathrm{C}$ determination and ancient palaeodiet analysis (in Chinese). Archaeology, 1984, 10: 949-955

10 Zhang X L. Study on the diet of ancient people by analyzing bone elements and isotopes (in Chinese). Acta Anthropol Sin, 2003, 22: 75-84

11 Hu Y W, Ambrose S H, Wang C S. Stable isotopic analysis of human bones from Jiahu site, Henan, China: Implications for the transition to agriculture. J Archaeol Sci, 2006, 33: 1319-1330

12 Fu Q M, Jin S A, Hu Y W. Agricultural development and human diets in Gouwan site, Xichuan,Henan. Chinese Sci Bull, 2010, 7: 614-620

13 Zhu C, Zheng C G, Ma C M, et al. Identifying paleoflood deposits archived in Zhongba Site, the Three Gorges reservoir region of the Yangtze River, China. Chinese Sci Bull, 2005, 50: 2493-504

14 Lee-Thorp J A, Merwe N J. Carbon isotope analysis of fossil bone apatite. S Afr J Sci, 1987, 83: 712-715

15 Merwe N J, Medina E. Photosynthesis and ${ }^{13} \mathrm{C} /{ }^{12} \mathrm{C}$ ratios in Amazon rain forests. Geochim Cosmochim Acta, 1989, 53: 1091-1094

16 Wang Y, Deng T. A 25 m.y. isotopic record of paleodiet and environmental change from fossil mammals and paleosols from the NE margin of the Tibetan Plateau. Earth Planet Sci Lett, 2005, 236: 322-338

17 Jenkins S G, Partridge S T, Stephenson T R, et al. Nitrogen and carbon isotope fractionation between mothers, neonates, and nursing offspring. Oecologia, 2001, 129: 336-341

18 Ambrose S H. Effects of diet, climate and physiology on nitrogen isotope abundances in terrestrial foodwebs. J Archaeol Sci, 1991, 18: 293-317

19 Iacumin P, Nikolaev V, Ramigni M. C and N stable isotope measurements on Eurasian fossil mammals, 40000 to 10000 years BP: Herbivore physiologies and palaeoenvironmental reconstruction. $\mathrm{Pa}$ laeogeogr Palaeoclimatol Palaeoecol, 2000, 163: 33-47

20 Joan B C, John M H, Thure E C, et al. Stable isotope biogeochemis- try and its implications for the palaeoecology of late Pleistocene, coastal southern California. Palaeogeogr Palaeoclimatol Palaeoecol, 2004, 205: 199-219

21 Flad R K. Specialized salt production and changing social structure at the prehistoric site of Zhongba in the Eastern Sichuan Basin, China. Dissertation for the Doctoral Degree. Los Angeles: University of California, 2004. 235-270

22 Koch P L, Tuross N, Fogel M L. The effects of sample treatment and diagenesis on the isotopic integrity of carbonate in biogenic hydroxylapatite. J Archaeol Sci, 1997, 24: 417-429

23 Abdulla A. Stable carbon isotope analysis of human tooth enamel from the Bronze Age cemetery of Ya'amoun in Northern Jordan. J Archaeol Sci, 2004, 31: 1693-1698

24 Kerstin L. Megaliths, agriculture and social complexity: A diet study of two Swedish megalith populations. J Anthropol Archaeol, 1995, 14: 404-417

25 Deniro M J. Post-mortem preservation and alteration of in vivo bone collagen isotope ratios in relation to paleodietary reconstruction. Nature, 1985, 317: 806-809

26 Iacumin P, Bocherens H, Delgado H A, et al. A stable isotope study of fossil mammal remains from the Paglicci cave, Southern Italy: N and C as palaeoenvironmental indicators. Earth Planet Sci Lett, 1997, 148: $349-357$

27 France R. Carbon isotope ratios in logged and unlogged boreal forests: Examination of the potential for determining wildlife habitat use. Environ Man, 1996, 20: 249-255

28 Pechenkina E A, Ambrose S H, Ma X L, et al. Reconstructing northern Chinese Neolithic subsistence practices by isotopic analysis. J Archaeol Sci, 2005, 32: 1176-1189

29 Masao M, Akira M, Naotaka I. Patterns of prehistoric boar Sus scrofa domestication, and inter-islands pig trading across the East China Sea, as determined by carbon and nitrogen isotope analysis. Chem Geol, 2005, 218: 91-102

30 Delwiche C C, Zinke P J, Johnson C M, et al. Virginia, nitrogen isotope distribution as a preservative indicator of nitrogen fixation. Bot Gaz, 1979, 140: 565-569

31 Tian X S, Zhu C, Xu X W, et al. Reconstructing past subsistence patterns on Zhongba Site using stable carbon and oxygen isotopes of fossil tooth enamel. Chinese Sci Bull, 2008, 53 (Suppl 1): 87-94

32 Ekaterina A P, Stanley H A, Ma X L, et al. Reconstructing northern Chinese Neolithic subsistence practices by isotopic analysis. J Archaeol Sci, 2005, 32: 1176-1189

33 Ambrose S H. Effects of diet, climate and physiology on nitrogen isotope abundances in terrestrial foodwebs. J Archaeol Sci, 1991, 18: 293-317

34 White C D, Pohl E D, Schwarcz H P, et al. Isotopic evidence for Maya patterns of deer and dog use at preclassic colha. J Archaeol Sci, 2001, 28: 89-107

35 O'Leary M H. Carbon isotopes in photosynthesis. Bioscience, 1998, 38: $328-336$

36 Ambrose S H, Deniro M J. Climate and habitat reconstruction using stable carbon and nitrogen isotope ratios of collagen in prehistoric herbivore teeth from Kenya. Quat Res, 1989, 31: 407-422

37 Hedges E M, Stevens R E, Richards M P. Bone as a stable isotope archive for local climatic information. Quat Sci Rev, 2004, 23: 959-965

38 Zhu C, Ma C M, Ouyang J, et al. Animal diversities and characteristics of environmental change revealed by skeletons unearthed at Zhongba Site of Chongqing City, China. Chinese Sci Bull, 53(Suppl 1): 74-86

39 Zhang Q, Zhu C, Jiang F Q, et al. Environmental archaeological exploration in Zhangjiawan Site, Chongqing since $2 \mathrm{ka} \mathrm{BP}$ (in Chinese). Acta Geogr Sin, 2001, 53: 353-362

40 Kathryn A H, Sue S, Ronald A. The implications for paleodietary and paleoclimatic reconstructions of intrapopulation variability in the oxygen and carbon isotopes of teeth from modern feral horses. Quat Res, 2005, 64: 138-146

Open Access This article is distributed under the terms of the Creative Commons Attribution License which permits any use, distribution, and reproduction in any medium, provided the original author(s) and source are credited. 